\title{
Transcriptional Regulation of the Mercury-resistance Genes of Transposon Tn501
}

\author{
By PETER A. LUND,* SIMON J. FORD† AND NIGEL L. BROWN \\ Department of Biochemistry and Unit of Molecular Genetics, University of Bristol, \\ University Walk, Bristol BS8 ITD, UK
}

(Received 8 July 1985; revised 30 August 1985)

\begin{abstract}
Expression of the mercury-resistance (mer) genes of the transposon Tn501 is positively and negatively controlled by the product of the mer $R$ gene. DNA sequence analysis has identified three open reading frames as potential candidates for this gene, one of which is oriented divergently with respect to the mercury-resistance genes. We have demonstrated that although RNA polymerase will bind to fragments containing the potential control regions for all three reading frames, only the control region for this divergent reading frame shows detectable promoter activity in vivo. Transcription of this reading frame is required for repression and induction of mer transcription. We have also shown that the Tn501 mer $R$ gene product negatively regulates its own synthesis, and have identified the start point of the transcript for this reading frame and for the mercury-inducible transcript of the mercury-resistance genes.
\end{abstract}

\section{INTRODUCTION}

Resistance to the toxic $\mathrm{Hg}(\mathrm{II})$ ion is widespread in bacteria, being detected in clinical isolates and in soil or water isolates from mercury-polluted areas (Summers \& Silver, 1978; Robinson \& Tuovinen, 1984; Silver \& Misra, 1984). The resistance determinant is often plasmid-borne. In the majority of cases described, resistance is mediated by mercuric reductase, an FADcontaining protein which reduces $\mathrm{Hg}(\mathrm{II})$ to elemental mercury $\mathrm{Hg}(0)$, which is less toxic and is rapidly volatilized. Physical and genetic studies, most notably on the mercury-resistance plasmid R100, together with DNA sequence analysis of the closely related mercury-resistance genes of R100 and transposon Tn501, have suggested the involvement of several other proteins in the expression of the resistance phenotype (Foster et al., 1979; Ni'Bhriain et al., 1983; Misra et al., 1984, 1985; Barrineau et al., 1985). A model for the molecular basis of $\mathrm{Hg}(\mathrm{II})$ resistance has been proposed, involving periplasmic, membrane and cytoplasmic components, based on mutational studies in R100 and on the features of the polypeptides predicted from the DNA sequence data from Tn501 and R100 (Misra et al., 1984; Brown, 1985).

The mercury-resistance genes of $\mathrm{R} 100$ and $\mathrm{Tn} 501$ appear to be organized as single transcriptional units, the transcription of which is inducible by subtoxic amounts of $\mathrm{Hg}$ (II). The use of transposon mutagenesis and of $\mathrm{Mu} \mathrm{d}\left(\mathrm{Ap}^{\mathrm{r}}\right.$ lac $)$ transcriptional fusions in $\mathrm{R} 100$ has shown that a separately transcribed gene, merR, is responsible for this induction (Foster et al., 1979; Ni'Bhriain et al., 1983). The $m e r R$ gene appears to be negatively autoregulated and to repress the transcription of the mer operon in the absence of $\mathrm{Hg}$ (II) (Ni'Bhriain et al., 1983). Mercuryresistance plasmids from different incompatibility groups are closely related, as shown by the fact that 10 out of 11 such plasmids from different isolates were found to be capable of complementing a merR mutant of R100 (Foster \& Ginnity, 1985).

† Present address: Program in Social Ecology, University of California, Irvine, CA 92717, USA.

Abbreviations: ORF, open reading frame; X-gal, 5-bromo-4-chloro-3-indolyl $\beta$-D-galactopyranoside. 
DNA sequence analysis of the mer $R$ region of both $\mathrm{Tn} 501$ and $\mathrm{R} 100$ has revealed three open reading frames (ORFs) which could code for the MerR protein (Misra et al., 1984; Barrineau et al., 1985). Using the Tn 501 sequence data to provide coordinates and numbering from the end of the left-hand inverted repeat sequence, these are from positions 232-414 and 195-374 on the top strand and positions 548-114 on the bottom strand (Fig. 1). These will be referred to as ORFs 1 , 2 and 3 respectively. Inspection of the DNA sequence alone is insufficient to decide which of these ORFs codes for the MerR protein. Potential promoter sequences exist for all three ORFs, although none of the three ORFs possesses a good ribosome binding-site. The effector, $\mathrm{Hg}(\mathrm{II})$, is most likely to bind to proteins with sulphydryl groups and all three ORFs contain codons for cysteine.

In order to study the regulation of transcription of $\mathrm{Tn} 501$ in more detail we have investigated the potential promoter regions. Initially we determined which restriction fragments were preferentially retained on nitrocellulose filters by purified RNA polymerase. Subsequently we cloned fragments of interest into a plasmid containing a promoterless $l a c Z$ gene and looked for expression of $\beta$-galactosidase. S1 nuclease mapping was used to detect transcripts and locate their start points. To determine the merR ORF, we cloned the merR region in various orientations with respect to the chloramphenicol acetyltransferase promoter in the plasmid pACYC184. We conclude that ORF3 is the strongest candidate for the merR gene. Transcription of the mer genes, but not of merR, is induced by $\mathrm{Hg}$ (II). Similar conclusions have recently been drawn in a study on the regulation of transcription of the mer genes of R100 (Foster \& Brown, 1985).

\section{METHODS}

Strains and plasmids. Plasmid transformations and $\beta$-galactosidase assays were done in a $\mathrm{Rec}^{-}$derivative of Escherichia coli CSH26 (Ara- $\Delta$ (lac-pro) Thi-; Miller, 1972), except for manipulations involving pUC9 or M13

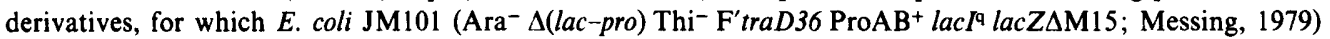
was used. The plasmids used are listed in Table 1 ; the construction of plasmids for this work is described below.

Media and chemicals. Media components were from Difco. Chemicals were from Sigma or BDH and were AnalaR grade when available. Restriction endonucleases, other enzymes for DNA manipulations and EcoRI linker oligonucleotides were from Boehringer, BRL or Sigma, except for restriction endonucleases $E c o$ RI and SalGI (gifts of S. E. Halford), restriction endonuclease HgiAI (a gift of D. Jacobs) and DNA ligase (a gift of L. Evans). Radiochemicals were from Amersham. All enzymes were used as recommended by manufacturers or donors. Antibiotics were used at $50 \mu \mathrm{g} \mathrm{ml}^{-1}$ except for tetracycline $\left(15 \mu \mathrm{g} \mathrm{ml}^{-1}\right)$ and chloramphenicol $\left(30 \mu \mathrm{g} \mathrm{ml}^{-1}\right)$. LB and supplemented minimal media were prepared as described by Miller (1972).

DNA preparations. Large-scale DNA preparations were made by lysis of overnight cultures, followed by isopycnic centrifugation in $\mathrm{CsCl} /$ ethidium bromide gradients (Clewell \& Helsinki, 1969) and purification of the supercoiled plasmid DNA by 2-propanol extraction, dialysis, phenol extraction and ethanol precipitation. Smallscale DNA preparations were made from $2 \mathrm{ml}$ overnight cultures as described by Ish-Horowicz \& Burke (1981). All DNA preparations were stored in TE $(10 \mathrm{~mm}$-Tris/HCl, pH 8.0, $1 \mathrm{mM}-\mathrm{EDTA})$ at $4{ }^{\circ} \mathrm{C}$.

DNA manipulations. Restriction endonuclease digests were done as recommended by the suppliers. All other DNA manipulations were as described by Maniatis et al. (1982).

Electrophoresis and purification of DNA fragments. Restriction endonuclease digests and DNA samples were separated by electrophoresis in agarose $(0.8-1.5 \%, \mathrm{w} / \mathrm{v})$ containing $0.5 \mu \mathrm{g}$ ethidium bromide $\mathrm{ml}^{-1}$, buffered with $90 \mathrm{~mm}$-Tris/borate, $2 \mathrm{mM}$-EDTA at pH 8.3 (TBE), or in TBE-buffered polyacrylamide $(3 \cdot 5-8 \%$, w/v). Fragments were purified from agarose by electroelution, as described by Maniatis $e$ al. (1982), and from polyacrylamide by diffusion, as described by Maxam \& Gilbert (1980). Fragments were further purified by phenol extraction and ethanol precipitation, after which samples were sufficiently pure for all subsequent manipulations.

DNA sequence analysis. This was done either by the chain-termination method (Sanger et al., 1977) in the vectors M13mp8 and M13mp9, or by the chemical method (Maxam \& Gilbert, 1980).

RNA polymerase purification. RNA polymerase was purified from E. coli MRE600 (50 g) or from Pseudomonas aeruginosa PAO (12 g) by the method of Burgess \& Jendrisak (1975), with the exception that in the latter preparation the cells were disrupted by sonication. RNA polymerase assays were as described by Burgess (1969).

Filter-binding studies with RNA polymerase. The methods used to detect DNA fragments that were retained by RNA polymerase on nitrocellulose filters were essentially those described by Jones et al. (1977). Nicrocellulose filters were treated by boiling for $10 \mathrm{~min}$ in distilled water and stored at $4{ }^{\circ} \mathrm{C}$. DNA of either Tn501-containing plasmids or gel-purified EcoRI fragments of Tn 501 was nick-translated by standard methods (Maniatis $e t$ al., 1982), digested with restriction enzymes, extracted with phenol and precipitated with ethanol before use. In the 
Table 1. Plasmids used

\begin{tabular}{|c|c|c|c|}
\hline Plasmid & Resistance* & Reference $\dagger$ & $\underset{\text { phenotype }}{\mathrm{Hg}}$ \\
\hline pACYC184 & $\mathrm{Tc} \mathrm{Cm}$ & Chang \& Cohen (1978) & $\mathrm{s}$ \\
\hline $\mathrm{pAC}-\mathrm{E}_{\mathrm{S}} \mathrm{E}_{\mathrm{L}}$ & Tc & & $\mathbf{R}$ \\
\hline pAC-E & Tc & & SS \\
\hline $\mathrm{pAC}-\mathrm{E}_{\mathrm{L}}$ & Tc & & $\mathbf{S}$ \\
\hline pAC-EH-1 & Tc & & $\mathrm{S}$ \\
\hline pAC-EH-3 & Tc & & $\mathbf{S}$ \\
\hline $\mathrm{pAC}-\mathrm{EZ}-1$ & Tc & & $\mathbf{S}$ \\
\hline pAC-EZ-10 & Tc & & $\mathrm{S}$ \\
\hline pDU1161 & Ap $\mathrm{Km} \mathrm{Cm}$ & Ni'Bhriain et al. (1983) & SS \\
\hline $\mathrm{pICl}$ & $\mathrm{Col}^{\mathrm{imm}}$ & Ford (1981) & $\mathbf{R}$ \\
\hline pJOE114 & Ap & Brown et al. (1983) & $\mathbf{R}$ \\
\hline pRZ5255 & $\mathrm{Km}$ & Lambert \& Reznikoff (1985) & $\mathrm{s}$ \\
\hline pPL-lacUV5 & $\mathrm{Km}$ & & $\mathrm{S}$ \\
\hline pRZ-EB-3 & $\mathrm{Km}$ & & $\mathrm{S}$ \\
\hline pRZ-ES-3 & $\mathrm{Km}$ & & SS \\
\hline $\mathrm{pRZ}-\mathrm{H}-2$ & $\mathrm{Km}$ & & $\mathbf{S}$ \\
\hline $\mathrm{pRZ} \cdot \mathrm{H}-12$ & $\mathrm{Km}$ & & $S \S$ \\
\hline pRZ-H-18 & $\mathrm{Km}$ & & $\mathrm{s}$ \\
\hline pRZ-EHA-5 & $\mathrm{Km}$ & & $\mathrm{S}$ \\
\hline
\end{tabular}

- Ap, ampicillin; $\mathrm{Cm}$, chloramphenicol; Km, kanamycin; Tc, tetracycline; Col ${ }^{\mathrm{imm}}$, immune to colicin.

$\dagger$ Plasmids for which no reference is given are described in this paper.

$\ddagger$ Hg phenotype was determined by disc assay, as described by Foster et al. (1979). R, resistant; S, sensitive; SS, supersensitive.

$\S$ Strains containing this plasmid showed a slightly elevated sensitivity to $\mathrm{HgCl}_{2}$, for reasons which are not fully understood.

filter-binding experiments, RNA polymerase was diluted slowly (in order to minimize denaturation) into a solution of $0.1 \mu \mathrm{g}$ nick-translated DNA fragments in $10 \mathrm{~mm}$-Tris/ $\mathrm{HCl}, \mathrm{pH} 7.9,100 \mathrm{mM}-\mathrm{KCl}, 10 \mathrm{mM}^{-} \mathrm{MgCl}_{2}$, $0.1 \mathrm{mM}$-DTT, $0.1 \mathrm{~mm}$-EDTA, $50 \mu \mathrm{g}$ bovine serum albumin $\mathrm{ml}^{-1}$ (nuclease-free). After $30 \mathrm{~min}$ incubation at $37^{\circ} \mathrm{C}$, heparin was added to $20 \mu \mathrm{g} \mathrm{ml}^{-1}$ and ribonucleoside triphosphates (as required) were added to final concentrations of $100 \mu \mathrm{M}$. The incubation was continued at $37^{\circ} \mathrm{C}$ for a further $10 \mathrm{~min}$ and the samples were filtered through nitrocellulose filters (Sartorius, type SM 11305, pore size $0.45 \mu \mathrm{m}$ ). The filter was washed in $100 \mu \mathrm{l}$ of $10 \mathrm{~mm}$-Tris/ $\mathrm{HCl}, \mathrm{pH} 7.9,10 \mathrm{~mm}-\mathrm{MgCl}_{2}, 0.1 \mathrm{~mm}$-DTT, $0.1 \mathrm{~mm}$-EDTA, containing either $50 \mathrm{~mm}-\mathrm{KCl}$ (G-buffer) at $37^{\circ} \mathrm{C}$ or $1 \mathrm{M}-\mathrm{KCl}$ (V-buffer) at $0^{\circ} \mathrm{C}$. The filtrate was collected, the filter was re-washed in the same buffer and the retained fragments were eluted in $100 \mu \mathrm{l}$ of $20 \mathrm{mM}$-Tris/ $\mathrm{HCl}, \mathrm{pH} 7 \cdot 9,0 \cdot 2 \% \mathrm{SDS}$. DNA was precipitated from the filtrate and the eluate with ethanol and analysed by PAGE.

$\beta$-Galactosidase assays. These were done as described by $\mathrm{Miller}$ (1972). When induction with $\mathrm{HgCl}_{2}$ was studied, overnight cultures were diluted 1:50 in fresh, prewarmed broth and grown for 60 min before the addition of $\mathrm{HgCl}_{2}$ solution.

Plasmid transformation. $\mathrm{CaCl}_{2}$-treated cells were transformed as described by Dagert \& Ehrlich (1979). pDU1161 was transferred between cells by conjugation. All pDU1161-containing strains were grown at $30^{\circ} \mathrm{C}$ to prevent $\mathrm{Mu} \mathrm{d}\left(\mathrm{Ap}^{\mathrm{r}} \mathrm{lac}\right)$ induction.

Plasmid constructions. Tn50I contains EcoRI sites in the inverted repeats at the ends of the transposon and one within the merA gene. The plasmid pJOE114 (Brown et al., 1983) was used as a source of the two EcoRI fragments which contain $\mathrm{Tn} 501$ sequences. To construct the plasmids pAC- $\mathrm{E}_{\mathrm{S}} \mathrm{E}_{\mathrm{L}}, \mathrm{pAC}-\mathrm{E}_{\mathrm{S}}$ and $\mathrm{pAC}-\mathrm{E}_{\mathrm{L}}$, these two EcoRI fragments were ligated with EcoRI-cut, alkaline-phosphatase-treated pACYC184. Plasmids with inserts were identified by their sensitivity to chloramphenicol, and restriction endonuclease digests were used to determine the size and orientation of the inserts. Plasmid $\mathrm{pAC}-\mathrm{E}_{\mathrm{S}} \mathrm{E}_{\mathrm{L}}$ contains the two EcoRI fragments from $\mathrm{Tn} 501$ in the correct orientation to regenerate a functional $\operatorname{mer} A$ gene; only this orientation of the two fragments produces a mercuryresistant phenotype (Brown et al., 1983). The direction of transcription of the mer genes in this plasmid is the same as that of the chloramphenicol acetyltransferase gene of pACYC184 (Stuber \& Bujard, 1981). The plasmids pAC$\mathrm{E}_{\mathrm{S}}$ and $\mathrm{pAC}-\mathrm{E}_{\mathrm{L}}$ contain, respectively, the small and large $E c o \mathrm{RI}$ fragments from $\mathrm{Tn} 501$, in the same orientation as in $p A C-E_{S} E_{L}$. These three plasmids $\left(p A C-E_{S} E_{L}, p A C-E_{S}\right.$ and $p A C-E_{L}$ ) are reconstructions of the plasmids pSJF305, pSJF302 and pSJF304, described by Brown et al. (1983).

Plasmids containing potential mer $R$ coding sequences were made by converting either the $H$ inf $I$ site at position 556 or the HaeIII site at position 699 (see Fig. 5) into EcoRI sites by the attachment of the octanucleotide linker GGAATTCC and digestion with excess EcoRI. The fragments were then ligated into the EcoRI site in 

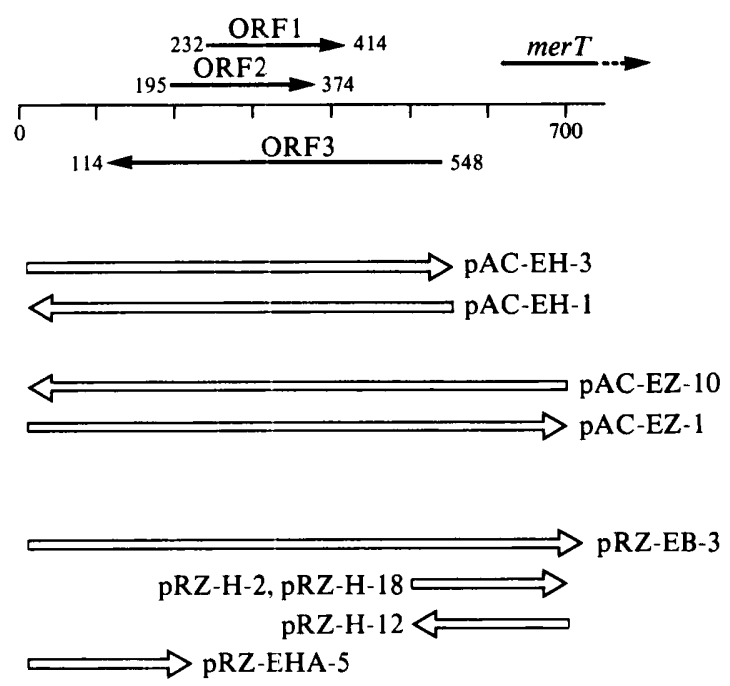

Fig. 1. Diagram of the first $750 \mathrm{bp}$ of Tn 501 . The three ORFs identified as candidates for the merR gene are shown as thick lines together with their co-ordinates on the DNA sequence. Arrowheads show the potential directions of transcription. The start of the mer $T$ gene is also shown. The open boxes indicate the regions cloned in plasmids, as described in Methods. The 'pRZ-' series were derived from the promoter probe $\mathrm{pRZ}$ 2525, which contains a promoterless lacZ gene; the arrowheads point towards the lac $Z$ gene in each particular plasmid. The 'pAC-' series were derived from the vector pACYC184; the arrowheads show the direction of transcription of each cloned fragment from the plasmid-borne chloramphenicol acetyltransferase promoter.

pACYC184 and their orientations were determined by restriction mapping. Plasmids pAC-EZ-1 and pAC-EZ-10 contain nucleotides 14-700 of Tn50I in pACYC184 in opposite orientations; in pAC-EZ-1, ORFs 1 and 2 of merR should be transcribed from the promoter of the chloramphenicol acetyltransferase gene. Plasmids pAC-EH-1 and pAC-EH-3 contain the nucleotides 14-559 of Tn501 in pACYC184 in the same orientations as pAC-EZ-1 and pAC-EZ-10 respectively. The regions of $\mathrm{Tn} 501$ cloned in these plasmids are shown diagrammatically in Fig. 1.

Plasmids containing the entire control region of Tn 501 were made by ligating either EcoRI-SalGI-digested pJOE114 with EcoRI-SalGI-digested pRZ5255, or a partial Sau3AI digest of the purified small EcoRI fragment from pJOE114 with EcoRI-BamHI-digested pRZ5255. The plasmid pRZ5255 is a derivative of pBR322, containing a $\operatorname{trp} B-\operatorname{lac} Z$ fusion downstream of unique EcoRI, BamHI and SalGI restriction sites (Lambert \& Reznikoff, 1985). An active promoter inserted into this plasmid using these sites will express $\beta$-galactosidase if in the correct orientation. Following transformation of $\mathrm{CSH} 26\left(\mathrm{RecA}^{-}\right)$with the ligation products and growth of kanamycin-resistant colonies, plates were replica plated onto minimal media containing kanamycin and X-gal, with $\mathrm{HgCl}_{2}$ either absent or present at a concentration of $0 \cdot 1 \mathrm{\mu g} \mathrm{ml}^{-1}$. Colonies which were blue in the presence of $\mathrm{HgCl}_{2}$ and white in its absence were repurified; plasmid DNA was prepared from them and its structure was analysed by restriction mapping.

Plasmids containing the potential promoter regions of $\mathrm{Tn} 501$ upstream of the $l a c Z$ gene in the promoter probe pRZ5255 were made by first cloning the fragments of interest into SmaI- or EcoRI-SmaI-cut M13mp8 and sequencing them to determine their orientation, and then subcloning them as EcoRI-BamHI fragments (using the $E c o$ RI and BamHI site in the M13mp8 multiple cloning site) into EcoRI-BamHI-cut pRZ5255. Thus, pRZ-H-2 contains the HaeIII fragment from positions 500-700 oriented such that $\beta$-galactosidase synthesis would be directed by the mer promoter; pRZ-H-12 contains the same fragment but in the reverse orientation. pRZ-EHA-5 contains the EcoRI-HaeIII fragment from position 14-226 such that promoters for either ORF of merR on the top strand of Tn 501 would direct $\beta$-galactosidase synthesis. pRZ-H-18 contains the EcoRI-BamHI fragment from pRZ-H-2, in the same orientation but with the reading frame altered by filling in of the unique BamHI site present in pRZ-H-2 such that the potential fusion product from the merT N-terminus now has an in-frame stop codon after 68 amino acids; in pRZ-H-2 the merT N-terminal amino acids make an in-frame translational fusion with the trpB-lacZ fusion in pRZ5255. All potential promoter-containing plasmids were checked by recloning the inserted fragments into $\mathrm{M} 13 \mathrm{mp} 8$ and $\mathrm{M} 13 \mathrm{mp} 9$ and sequencing both strands. The regions of $\mathrm{Tn} 501$ cloned in these plasmids are shown diagrammatically in Fig. 1. 
A plasmid (pPL-lacUV5) containing the lacUVS promoter (Silverstone et al., 1970) was constructed by ligating into the EcoRI site in pRZ5255 an EcoRI fragment from the plasmid pPH66 (a gift from P. Hedge) which contains this promoter. A blue colony was picked from an X-gal-containing plate, and the presence of the EcoRI fragment was verified by restriction analysis.

Plasmid pICl was constructed in vivo by the transposition of Tn501 into the plasmid pMB8 (Ford, 1981).

RNA preparation and S1 mapping. These were done by the methods described by Berk \& Sharp (1977).

\section{RESULTS}

\section{RNA polymerase binding studies}

Initial experiments in which the binding of $E$. coli RNA polymerase to pIC1 DNA was examined showed that three strong RNA polymerase binding sites were present. These were all associated with the pMB8 sequences present in $\mathrm{pICl}$, and were therefore derived from the ColE1 plasmid. The Tn501 sequences had much lower affinity for RNA polymerase. This is consistent with the positive regulation of the mer region of Tn501. Subsequent experiments showed that the binding of RNA polymerase from $P$. aeruginosa to fragments of Tn501 DNA were qualitatively similar to that of the $E$. coli enzyme (Ford, 1981).

The results of experiments in which $P$. aeruginosa RNA polymerase was bound to HaeIII fragments from the small EcoRI fragment of Tn501 (nucleotides 13-2358) are shown in Fig. 2. The fragment corresponding to nucleotides $500-700$ was retained on the filter after washing with V-buffer at $0{ }^{\circ} \mathrm{C}$ in the presence of both combinations of ribonucleoside triphosphates. There was no retention if the ribonucleotides were absent, and the retention was stronger in the presence of GTP, ATP and CTP than in the presence of GTP, ATP and UTP. If the filter was washed under milder conditions (G-buffer at $37^{\circ} \mathrm{C}$ ), this fragment was retained in the absence of ribonucleoside triphosphates, and other fragments were retained when the ribonucleotides were present. These data are consistent with the fragment 500-700 being the fragment on which RNA polymerase can initiate a transcript and form a stable complex with DNA. Binding to the other DNA fragments only occurs when the filter is washed under less severe conditions, and the fragments retained in these cases probably represent non-initiating but tight-binding complexes of RNA polymerase with DNA.

\section{Construction and properties of lacZ transcriptional fusions to potential mer and merR promoters}

Derivatives of pRZ5255 containing the entire control region of Tn501 were constructed as described in Methods and their structures were determined by restriction analysis. The plasmid pRZ-ES-3 contained an EcoRI-SalGI fragment from Tn501 (nucleotides 14-1885) and the plasmid pRZ-EB-3 (shown in Fig. 1) contained an EcoRI-Sau3AI fragment from Tn501 (nucleotides 14-712). In both cases these fragments spanned the mer control regions and were oriented such that transcription of the lac $Z$ gene in pRZ5255 would be from the mer promoter. Strains containing these plasmids were assayed for $\beta$-galactosidase activity over a range of concentrations of $\mathrm{HgCl}_{2}$. The results, shown in Fig. 3, show clear induction of $\beta$-galactosidase by $\mathrm{HgCl}_{2}$.

There is a significant difference in the response of strains containing the two plasmids to the same amount of $\mathrm{HgCl}_{2}$, despite that fact that transcription is presumably from the same promoter in each case. Although there will be an effect due to the different separations of the site of initiation of transcription and the lac $Z$ gene, the different capacities of these strains for transporting $\mathrm{Hg}(\mathrm{II})$ into the cell is also likely to account for this result (see Discussion). For the studies which are described below on the other promoter-containing plasmids, $1 \mu \mathrm{g} \mathrm{HgCl}_{2} \mathrm{ml}^{-1}$ was chosen as the standard concentration used for induction, except where the strains contained a plasmid conferring a high level of sensitivity to $\mathrm{HgCl}_{2}$, where $0 \cdot 1 \mu \mathrm{g} \mathrm{ml}^{-1}$ was used.

In order to isolate the potential regulatory regions involved both in $m e r R$ and $m e r$ transcription, the plasmids pRZ-H-2, pRZ-H-12 and pRZ-EHA-5 were constructed. Strains were then made that contained one of these plasmids with either $\mathrm{pACYC} 184$ or $\mathrm{pAC}-\mathrm{E}_{\mathrm{S}} \mathrm{E}_{\mathrm{L}}$ also present and $\beta$-galactosidase assays were done with or without induction with $\mathrm{HgCl}_{2}$ (Table 2). 


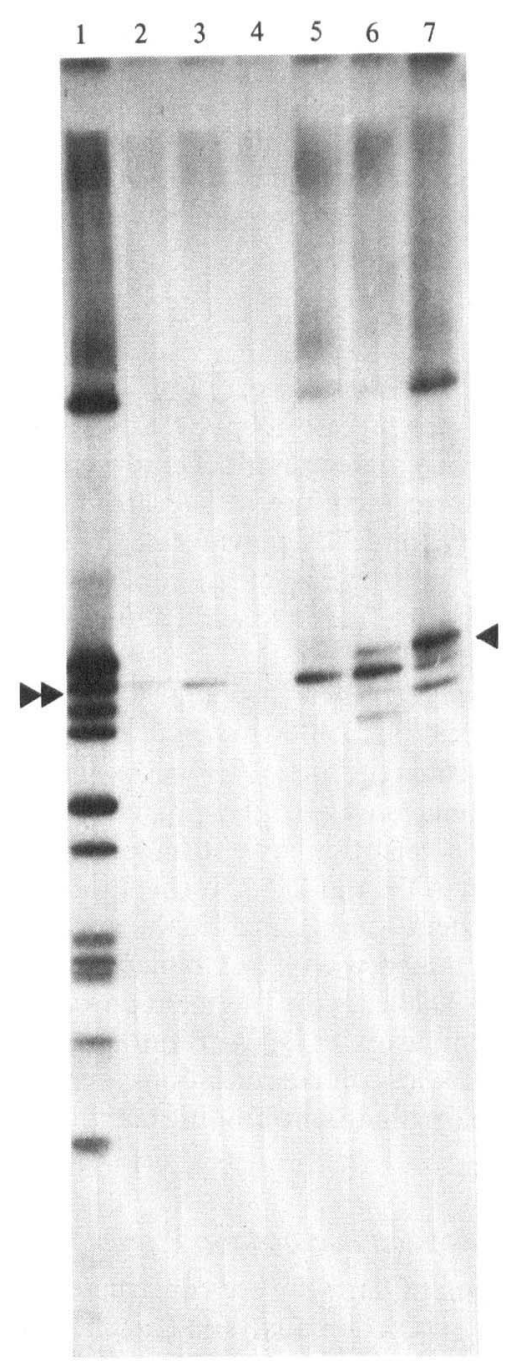

Fig. 2. Filter-retention by RNA polymerase of HaeIII fragments of the small EcoRI fragment of Tn501 DNA. RNA polymerase was present at a ratio of 62.5 units of enzyme per $\mu \mathrm{g}$ DNA. Track 1 is a HaellI digest of the nick-translated DNA, tracks 2-7 are the fragments retained on the filter by RNA polymerase. The nucleotides present during the binding step and the conditions used to wash the filter were as follows. Track 2: GTP, ATP and UTP; V-buffer, $0^{\circ} \mathrm{C}$. Track 3: GTP, ATP and CTP; V-buffer, $0{ }^{\circ} \mathrm{C}$. Track 4: no triphosphates; V-buffer, $0{ }^{\circ} \mathrm{C}$. Track 5: no triphosphates; G-buffer, $37^{\circ} \mathrm{C}$. Track 6: GTP, ATP and CTP; G-buffer, $37^{\circ} \mathrm{C}$. Track 7: GTP, ATP and UTP; G-buffer, $37^{\circ} \mathrm{C}$. The double arrowhead marks the fragment containing nucleotides $500-700$ of Tn501, and the single arrowhead marks that containing nucleotides 13-226.

Both pRZ-H-2 and pRZ-H- 12 show low but measurable $\beta$-galactosidase activity when there is no Tn501 present in the cell. The introduction of Tn501 in trans on the plasmid pAC- $\mathrm{E}_{\mathrm{S}} \mathrm{E}_{\mathrm{L}}$ causes a marked decrease in the $\beta$-galactosidase activity. In the control strains containing the plasmid pPL-lacUV5 with either pACYC184 or pAC- $\mathrm{E}_{\mathrm{S}} \mathrm{E}_{\mathrm{L}}$, the decrease in the $\beta$-galactosidase activity in the presence of $\mathrm{pAC}-\mathrm{E}_{\mathrm{S}} \mathrm{E}_{\mathrm{L}}$ is proportionally much smaller. This therefore suggests that the plasmids $\mathrm{pRZ}-\mathrm{H}-2$ and $\mathrm{pRZ}-\mathrm{H}-12$ contain promoters which are repressed by a product of Tn 501 , the most likely candidate being the merR gene product. In contrast, the plasmid pRZEHA-5, containing the potential control regions for the two possible reading frames ORF1 and ORF2 for merR on the top strand of Tn 501 , shows approximately the same level of activity as the promoter-less control plasmid pRZ5255, irrespective of the presence or absence of Tn501 in the same cell. The strain containing pRZ-H-2 and Tn 501 shows clear stimulation of transcription when $\mathrm{HgCl}_{2}$ is added to the growth medium 30 min before assay. This is consistent with this plasmid containing the promoter for transcription of the mer operon, as was predicted from the DNA sequence analysis of the fragment. The strain containing pRZ-H-12 and Tn 501 shows no $\mathrm{Hg}$ (II) stimulation of transcription.

From the known sequence of the region of pRZ5255 into which the mer regulatory region was cloned (W. S. Reznikoff, personal communication), it was predicted that $\mathrm{Hg}$ (II) induction 


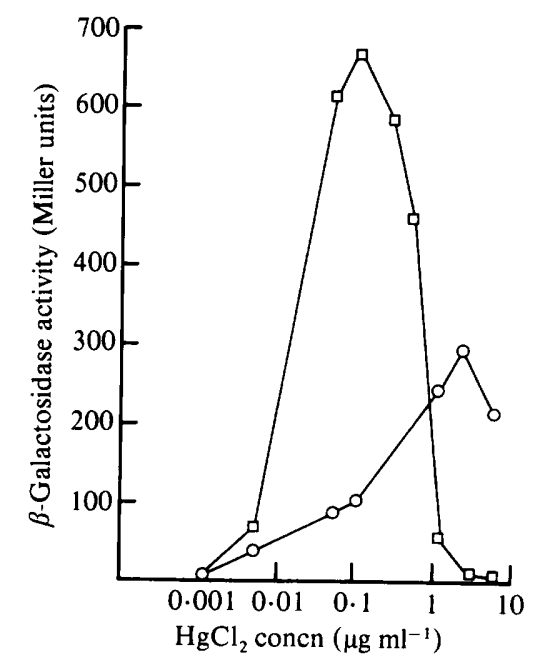

Fig. 3. Induction of $\beta$-galactosidase activity from the plasmids pRZ-ES-3 ( $\square$ ) and pRZ-EB-3 (O) over a range of $\mathrm{HgCl}_{2}$ concentrations. Units of activity of $\beta$-galactosidase were determined and expressed as described by Miller (1972).

Table 2. Induction of $\beta$-galactosidase activity by $\mathrm{Hg}(\mathrm{II})$ from derivatives of $\mathrm{pRZ} 2555$ in the presence or absence of Tn501 in trans

Units of $\beta$-galactosidase activity were determined and expressed as described by Miller (1972). Values are means from at least two independent determinations.

\begin{tabular}{|c|c|c|c|c|}
\hline \multirow[b]{2}{*}{ Plasmid } & \multirow[b]{2}{*}{$\begin{array}{l}\text { Presumptive } \\
\text { promoter(s) }\end{array}$} & \multirow[b]{2}{*}{$\begin{array}{c}\mathrm{Hg}(\mathrm{II}) \\
\left(\mu \mathrm{g} \mathrm{ml}^{-1}\right)\end{array}$} & \multicolumn{2}{|c|}{ Complementing plasmid } \\
\hline & & & pACYC184 & $p A C-E_{S} E_{L}$ \\
\hline $\mathrm{pRZ}-\mathrm{H}-2$ & mer & $\begin{array}{l}0 \\
1\end{array}$ & $\begin{array}{l}22 \cdot 4 \\
22 \cdot 1\end{array}$ & $\begin{array}{r}11.9 \\
377.1\end{array}$ \\
\hline $\mathrm{pRZ}-\mathrm{H}-18$ & mer & $\begin{array}{l}0 \\
1\end{array}$ & $\begin{array}{l}18 \cdot 8 \\
\text { ND }\end{array}$ & $\begin{array}{r}7.6 \\
524 \cdot 4\end{array}$ \\
\hline pRZ-H-12 & ORF3 & $\begin{array}{l}0 \\
1\end{array}$ & $\begin{array}{l}22 \cdot 3 \\
24 \cdot 0\end{array}$ & $\begin{array}{l}10.9 \\
11.9\end{array}$ \\
\hline pRZ-EHA-5 & ORF1 and ORF2 & $\begin{array}{l}0 \\
1\end{array}$ & $\begin{array}{l}3 \cdot 6 \\
6 \cdot 3\end{array}$ & $\begin{array}{l}7 \cdot 7 \\
7 \cdot 0\end{array}$ \\
\hline $\mathrm{pRZ} 5255$ & None & $\begin{array}{l}0 \\
1\end{array}$ & $\begin{array}{r}8 \cdot 5 \\
10 \cdot 2\end{array}$ & $\begin{array}{l}6 \cdot 5 \\
6 \cdot 4\end{array}$ \\
\hline pPL-lacUV5 & lacUV5 & $\begin{array}{l}0 \\
1\end{array}$ & $\begin{array}{l}268 \cdot 0 \\
261 \cdot 4\end{array}$ & $\begin{array}{l}220 \cdot 3 \\
230 \cdot 7\end{array}$ \\
\hline
\end{tabular}

ND, Not determined.

would lead to the synthesis of a translational fusion product between the $\mathrm{N}$-terminus of merT and the $\operatorname{trp} B-l a c Z$ fusion present downstream. To investigate whether or not this had any significant effect on the $\beta$-galactosidase activity, the ORF of the mer $T$ fusion was changed by filling in the Bam HI site; this put the merT N-terminus in frame with a translational stop codon $207 \mathrm{bp}$ downstream from the $\mathrm{N}$-terminal methionine codon of merT. Strains containing the new plasmid, designated pRZ-H-18, were assayed for $\beta$-galactosidase activity under the same conditions as the plasmids pRZ-H-2 and pRZ-H-12. Essentially the same pattern of $\beta$ galactosidase activity was seen with $\mathrm{pRZ}-\mathrm{H}-18$ as with $\mathrm{pRZ}-\mathrm{H}-2$, although the constitutive and repressed levels were slightly lower, and the induced level somewhat higher in pRZ-H-18 than in pRZ-H-2 (Table 2). 
Table 3. Effects of merR-containing plasmids on levels of $\beta$-galactosidase synthesized from Tn501 and R100 mer promoters, and the Tn501 ORF3 promoter

Units of $\beta$-galactosidase activity were determined and expressed as described by Miller (1972). Values are means from at least two independent determinations.

$\begin{array}{cc}\begin{array}{c}\text { Promoter } \\ \text { plasmid }\end{array} & \begin{array}{c}\mathrm{Hg}(\mathrm{II}) \\ \left(\mu \mathrm{g} \mathrm{m}^{-1}\right)\end{array} \\ \text { pRZ-H-2 } & 0 \\ & 1 \\ \text { pDU1161 } & 0 \\ \text { pRZ-H-12 } & 0 \cdot 1\end{array}$

\begin{tabular}{ccccc}
\multicolumn{5}{c}{ Complementing plasmid } \\
pAC-EZ-1 & pAC-EZ-10 & pAC-EH-1 & pAC-EH-3 & pACYC184 \\
12.8 & 10.0 & 19.5 & 8.3 & 22.4 \\
111.1 & 203.2 & 19.6 & 195.8 & 22.1 \\
56.1 & ND & 103.0 & 54.3 & 100.9 \\
684.9 & ND & 88.1 & 1651.9 & 101.8 \\
12.5 & 7.2 & 21.3 & 6.8 & 22.4
\end{tabular}

ND, Not determined.

\section{Construction of and complementation by plasmids expressing the merR gene product}

The availability of clones which detect $\mathrm{Hg}(\mathrm{II})$-induced transcription from the mer promoter provides a simple in vivo assay for the detection of plasmid clones which express the merR function. By constructing the appropriate clones, it should be possible to determine which of the three potential ORFs detected by DNA-sequencing codes for the mer $R$ gene product. Complementation tests could be carried out using pACYC184 and pRZ5255 derived plasmids in the same cell, as the two parental replicons are compatible (Chang \& Cohen, 1978).

Initially, it was confirmed that the merR activity was located in the smaller EcoRI fragment from $\mathrm{Tn} 501$, by constructing plasmid clones $\mathrm{pAC}-\mathrm{E}_{\mathrm{S}}$ and $\mathrm{pAC}-\mathrm{E}_{\mathrm{L}}$ that contained either the small or large EcoRI fragments from $\mathrm{Tn} 501$. As expected, $\mathrm{Hg}$ (II)-dependent induction of the mer promoter in the plasmid pRZ-H-2 was seen only when the small EcoRI fragment was present in the same cell (results not shown). The plasmids pAC-EZ-1, pAC-EZ-10, pAC-EH-1 and pAC-EH-3 were then constructed as described in Methods and their effect on transcription from pRZ-H-2 in the presence or absence of $\mathrm{Hg}(\mathrm{II})$ was studied.

The results of these experiments (Table 3) provide strong support for the hypothesis that ORF3 is the mer $R$ gene. Thus, induction and repression of mer transcription is seen when nucleotides 14-700 of Tn501 are present, irrespective of their orientation (pAC-EZ-1 and pACEZ-10). This fragment contains all three ORFs and all their presumptive control regions. However, in the plasmids pAC-EH-1 and pAC-EH-3 (where cutting at the Hinfl site immediately proximal to the ATG initiation codon of ORF3 has removed the control region of ORF3 but left the other two intact), induction and repression of mer transcription is seen only when the orientation of the EcoRI fragment is such that ORF3 can be transcribed from the chloramphenicol acetyltransferase promoter of pACYC184. Inspection of the known DNA sequence of the chloramphenicol acetyltransferase gene (Alton \& Vapnek, 1979) shows that the plasmid pAC-EH-3 will contain a translational fusion between the N-terminus of the chloramphenicol acetyltransferase and the entire coding region for ORF3.

Two further experiments were done to see whether these four plasmids expressed the other functions ascribed to merR. First, their ability to inhibit transcription from the plasmid containing the proposed mer $R$ promoter (pRZ-H-12) was investigated. Repression was seen, except with pAC-EH-1 (Table 3), supporting the hypothesis that the merR gene product negatively autoregulates its own synthesis, as has been proposed for the R100 system (Ni'Bhriain et al., 1983). Also, plasmid pAC-EZ-1 was less effective than plasmid pAC-EZ-10 at directing induction of mer transcription. This may be because in plasmid pAC-EZ-10, ORF3 could be transcribed both from its own promoter and the promoter for the chloramphenicol acetyltransferase gene, leading to higher intracellular levels of MerR protein. The lower levels of $m e r R$ activity in strains containing pAC-EZ-1 may be a result both of lower transcription and possibly of impaired translation of the $m e r R$ mRNA, since the opposite strand will also be transcribed from the chloramphenicol acetyltransferase promoter to produce 'anti-sense' mRNA, which is known to be capable of lowering translation efficiency (Pestka et al., 1984). 
Secondly, the abilities of the different plasmids to complement a merR mutant derived from $\mathrm{R} 100$ were tested. The plasmid used for these experiments was pDU1161, which contains a Tn 5 insertion in the merR gene, and a $\mathrm{Mud}\left(\mathrm{Ap}^{\mathrm{r}}\right.$ lac $)$ transcriptional fusion in the $m e r A$ gene (Ni'Bhriain et al., 1983). The relative levels of $\beta$-galactosidase expressed from this plasmid represent the relative amounts of transcription from the R100 mer operon promoter. The effects in trans of the Tn501-merR-containing plasmids (Table 3) show clear complementation of the $\mathrm{R} 100$ mer $R$ gene both for induction and repression, except in the plasmid where ORF3 is without a promoter.

\section{Transcriptional mapping of the mer and merR promoters}

RNA was prepared from CSH26 (RecA-) (pJOE114) which had been grown to midexponential phase and then induced for 30 min with 0.1 or $15 \mu \mathrm{g} \mathrm{HgCl}_{2} \mathrm{ml}^{-1}$. RNA was also prepared from the same strain without induction. DNA fragments which contained the mer promoter or the potential promoters for ORFs 1, 2 or 3 were end-labelled, purified, strandseparated and sequenced by the chemical method, all as described by Maxam \& Gilbert (1980), to identify each strand. The fragments used were the HinfI-AvaI fragment (positions 556-695) for the mer promoter, the HpaII fragment (positions 496-636) for the ORF3 promoter, and the EcoRI-HgiAI fragment (positions 14-276), which would contain the promoters for both ORFs 1 and 2. Hybrids made between the RNA preparations and the complementary strand from each fragment in turn were digested with nuclease S1 and analysed by denaturing PAGE. RNA preparations from induced and non-induced cells were analysed on the same gel. A chemical sequence analysis of the same fragment was run alongside the protected fragments so that the start point of transcription could be located on the DNA sequence.

The results of these S1 mapping experiments are shown in Fig. 4. A transcript is seen corresponding to ORF3 for merR (Fig. 4b, tracks 8-10). Comparison with the sequence shows that this initiates at position $576 \pm 1$. The presence or absence of $\mathrm{Hg}(\mathrm{II})$ has little or no effect on the levels of hybrid formed. Conversely, the transcript from the mer promoter is strongly induced by $\mathrm{Hg}$ (II) (Fig. $4 a$, tracks $2-4$ ). This protected hybrid starts at position $591 \pm 1$. A series of bands representing shorter hybrids is also visible. These bands were seen reproducibly with different RNA preparations, different S1 stocks and different hybridization conditions (not shown), but their significance in vivo, if any, is not known. The possibility that they represent multiple start points for initiation of transcription is lessened by the fact that some of these points would be after the beginning of $m e r T$, the first gene in the mer operon. No transcript could be detected in the absence of $\mathrm{Hg}$ (II) induction, even after prolonged exposure of the autoradiograph.

No transcript could be detected corresponding to either of the ORFs 1 or 2, even when $50 \mu \mathrm{g}$ RNA was used in the hybridization and the gel was autoradiographed for a long period (not shown). Attempts to detect transcripts by using single-stranded probes labelled by primer extension of an M13mp8 clone containing the EcoRI-HaeIII fragment (positions 14-226) were also unsuccessful. It therefore seems unlikely that ORFs 1 and 2 are transcribed in vivo from promoters within Tn501, although the possibility of very low levels of transcription cannot be completely eliminated.

\section{DISCUSSION}

Previous studies on the transposon Tn501 (Jackson \& Summers, 1982; Brown et al., 1983) have demonstrated that the mer operon is expressed only in the presence of $\mathrm{Hg}$ (II). We have shown here that, as with R100, transcription of the mer genes of Tn501 is regulated both positively and negatively by the mer $R$ gene product, which also negatively regulates its own synthesis. Activator genes generally show negative autoregulation in $E$. coli (Raibaud \& Schwarz, 1984). In most of the cases studied, the activator gene is orientated divergently with respect to the gene or genes which it regulates, for example araC (Wilcox et al., 1974), dsdC (McFall \& Heincz, 1983) and lysR (Stragier \& Patte, 1983). 
(a)

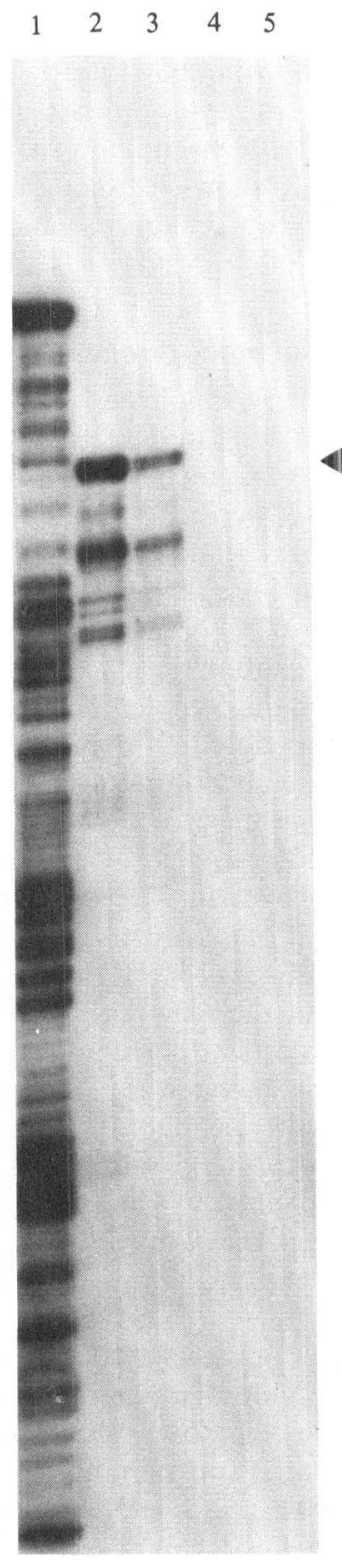

(b)

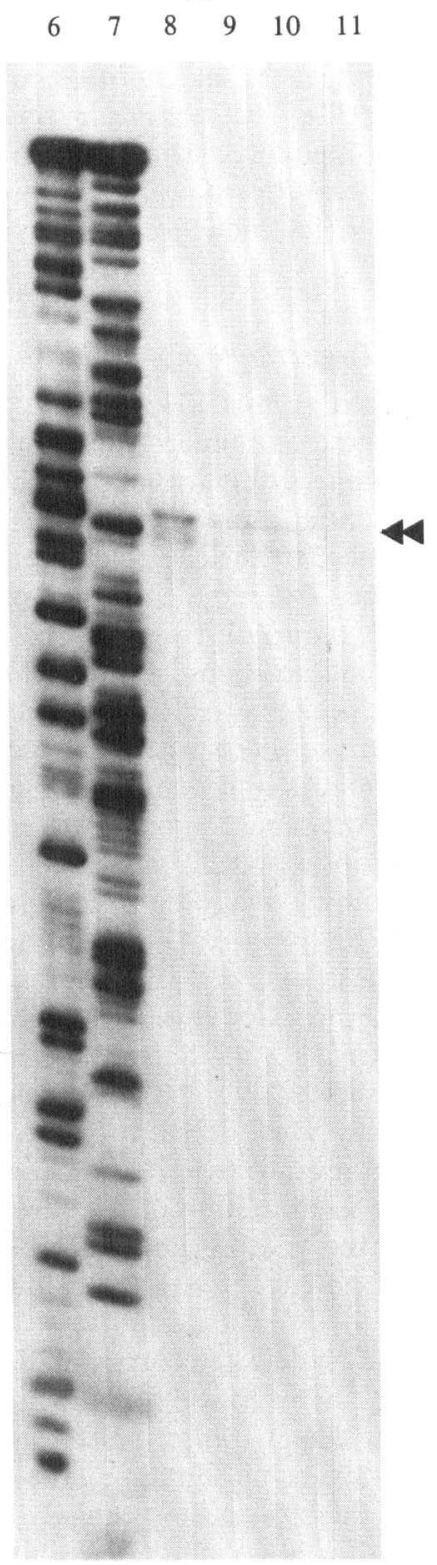

Fig. 4. Transcriptional mapping of the mer and merR promoters. (a) Results of S1 nuclease digestion of hybrids formed after $8 \mathrm{~h}$ incubation at $45^{\circ} \mathrm{C}$ between different RNA preparations and the bottom strand (see Fig. 1) of the Hinfl-AvaI fragment containing the mer promoter. RNA preparations were from CSH26 (RecA ${ }^{-}$) (pJOE114) induced for $30 \mathrm{~min}$ with $15 \mu \mathrm{g} \mathrm{HgCl}_{2} \mathrm{ml}^{-1}$ (track 2), $0 \cdot 1 \mu \mathrm{g} \mathrm{HgCl}_{2} \mathrm{ml}^{-1}$ (track 3), or not induced (track 4). Track 5 contains non-homologous RNA (prepared from Streptomyces lividans, a gift of $M$. Buttner). Track $I$ is the $T+C$ sequence of the DNA strand used in the hybridization. The amount of sample loaded in each of the tracks $2-5$ is equivalent to $5 \mu \mathrm{g}$ RNA in the initial hybridization mix. The arrowhead indicates the major protected fragment, corresponding to the initiation point of the mer transcript.

(b) Results of $\mathrm{S} 1$ nuclease digestion of hybrids formed after $8 \mathrm{~h}$ incubation at $45^{\circ} \mathrm{C}$ between the RNA preparations used in (a) and the top strand of the HpaII fragment, containing the promoter for ORF3 (see Fig. 1). The RNA preparations used in tracks 8-11 correspond to those in tracks 2-5 in (a); the amount of sample loaded in these tracks is equivalent to $25 \mu \mathrm{g}$ RNA in the original hybridization mix. Tracks 6 and 7 contain the $\mathrm{G}>\mathrm{A}$ and $\mathrm{T}+\mathrm{C}$ sequences of the HpalI fragment top strand. The double arrowhead indicates the protected fragment. corresponding to the presumed merR transcript. 
The DNA sequence of the Tn 501 regulatory region revealed three ORFs which could code for the $m e r R$ gene. We have shown that the divergent ORF is the most likely candidate for the mer $R$ gene. The most direct evidence for this was the demonstration that plasmids in which the control region for this $m e r R$ ORF was deleted only expressed $m e r R$ functions when a foreign promoter (the chloramphenicol acetyltransferase promoter) was in the correct position to transcribe this ORF. The predicted DNA sequence of this clone suggests that the merR gene product may be expressed as a fusion protein with the first 72 amino acids being derived from the chloramphenicol acetyltransferase coding sequence. The results in this paper show that if this fusion protein is the only product, then it has essentially the same properties as the wild-type MerR protein. However, the possibility that wild-type MerR protein is also produced by this plasmid by reinitiation of translation, and is responsible for the observed effects on transcription from the mer promoter, cannot be excluded. We have recently demonstrated that expression of the wild-type $m e r R$ gene alone from a foreign promoter (the tacII promoter; de Boer et al., 1983) has identical effects on transcription from the mer and $m e r R$ promoters to those described here (P. A. Lund, unpublished results).

Comparisons with studies on the plasmid R100 also support this conclusion. ORF1 in R100 has the potential to code for a protein of 120 amino acids. In $\mathrm{Tn} 501$, however, the corresponding ORF would code for a protein of only 59 amino acids. It seems unlikely that two proteins as similar in their function as the MerR proteins from Tn501 and R100 appear to be would differ in length to this extent. ORF2 would code for a protein of 40 amino acids in both Tn501 and R100. It is known from R 100 that deletion of the region distal to the HincII site at position 518 in R100 (corresponding to position 489 in $T n 501$ ) eliminates the merR function as monitored by induction of transcription by $\mathrm{Hg}(\mathrm{II})$ (Ni'Bhriain et al., 1983). The HincII site is beyond the termination codon for ORF2, and consequently this ORF cannot code for the induction function. A recent study in R100 has shown directly that the divergent ORF is the most likely candidate for the merR gene (Foster \& Brown, 1985).

It has been noted (Barrineau et al., 1985) that deletion of the 3 '-end of ORF3 does not abolish induction of mer transcription. The deletion, made in the mer region cloned from R100, corresponded to deletion up to position 161 in Tn501, and would hence remove the $15 \mathrm{C}$ terminal amino acids from merR. This has been adduced as evidence that ORF3 is not the correct ORF for merR. We believe it is more likely that the induction function of merR is unaffected by the loss of the $15 \mathrm{C}$-terminal amino acids that this deletion would represent.

RNA polymerase binding data provided a preliminary idea of where on the $\mathrm{Tn} 501$ sequence the major promoter(s) were located. Such experiments are adequate to do this, but are not in themselves sufficient demonstration of the site of transcription promoters. Although only complexes which have initiated a transcript are stable to treatment at low temperature and high ionic strength $\left(0^{\circ} \mathrm{C}, \mathrm{V}\right.$-buffer $)$, Melançon et al. (1982) have shown that $E$. coli RNA polymerase can form complexes at sites which are not in vivo promoters, yet which are competent to initiate transcription in vitro. Although formation of stable complexes of this type can be avoided by using very short incubation times during the binding assay, this would also fail to detect the positively-regulated promoter present in Tn501 and could not be used here. Our RNA polymerase binding data are consistent with the DNA fragment from nucleotides 500 to 700 of Tn 501 containing the promoter of the mer operon.

Under less stringent conditions for washing the filters (i.e. G-buffer, $37^{\circ} \mathrm{C}$ ), the fragments retained in the presence of triphosphates includes that from nucleotides 13 to 226 of Tn501, which would contain the regions required for transcription of ORFs 1 and 2. The retention of this and the other fragments may be due to the formation of non-initiating, tight-binding complexes at sequences homologous to those of promoters (Hawley \& McClure, 1983) and cannot be taken as firm evidence for the existence of a genuine promoter in this fragment.

We have shown, by cloning a fragment of DNA containing the promoter for the mer genes upstream of a promoterless $l a c Z$ gene, that the high level of expression of the mer genes in the presence of $\mathrm{Hg}(\mathrm{II})$ is due to positive control mediated by the $\operatorname{mer} R$ gene product. Strong induction of $\beta$-galactosidase is seen only in the presence of $\mathrm{Hg}(\mathrm{II})$ and the mer $R$ product (or the fusion polypeptide). S1 nuclease mapping demonstrated the presence of a $\mathrm{Hg}$ (II)-inducible transcript starting in this region. The absence of $m e r R$ leads to a low level of expression of lac $Z$, 
AAAATAAAGCACGCTAAGGCATAGCCGAACCTGCCAAGCTTGCTCCACCCTGTAGTGACGCGATCAGCGGGCAGGAAACGTTCCCCCTTC 190 TTTTATTTCGTGCGATTCCGTATCGGCTTGGACGGTTCGAACGAGGTGGGACATCACTGCGCTAGTCGCCCGTCCTTTGCAAGGGGGAAG

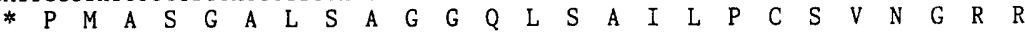
HaeII
2 CGGCCAGACTGCTGGCTTCCTCGCAATGGGTGCCATCCTCCAGCCGCAGCAGCTCGGCGATCTCATCCAGGCTGAAGCCCAGCCGCTGGG 370 GCCGGTCTGACGACCGAAGGAGCGTTACCCACGGTAGGAGGTCGGCGTCGTCGAGCCGCTAGAGTAGGTCCGACTTCGGGTCGGCGACCC $\begin{array}{lllllllllllllllllllllllllllllllllll}A & L & S & S & A & E & E & C & H & T & G & D & E & L & R & L & L & E & A & I & E & D & L & S & F & G & L & R & Q & A\end{array}$

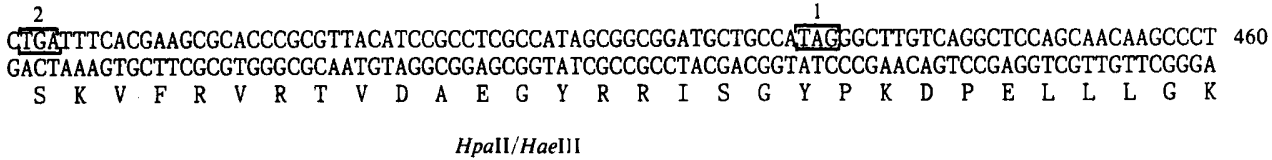

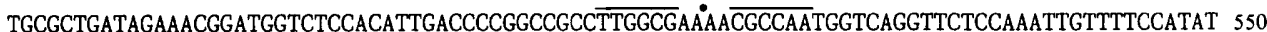
ACGCGACTATCTTTGCCTACCAGAGGTGTAACTGGGGCCGGGGAACCGCTTTTGCGGTTACCAGTCCAAGAGGTTTAACAAAAGGTATA

$\begin{array}{lllllllllllllllllllllllllllllllll}R & Q & Y & F & R & I & T & E & V & N & V & G & A & A & K & A & F & V & G & I & T & L & N & E & L & N & N & E & M\end{array}$

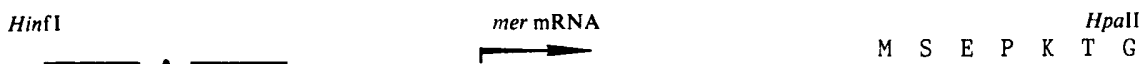

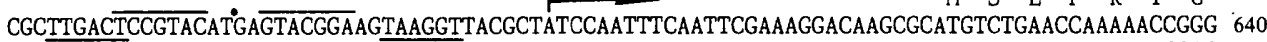
GCGAACTGAGGCATGTACTCATGCCTTCATTCCAATGCGATAGGTTAAAGTTAAGCTTTCCTGTTCGCGTACAGACTTGGTTTTTGGCCC

$\operatorname{merR} \mathrm{mRNA}$

$\begin{array}{lllllllllllllllllllllllllllllllll}\text { R } & G & A & L & F & T & G & G & L & A & A & I & L & A & S & A & C & C & L & G & P & L & V & L & I & A & L & G & F & S\end{array}$ CGCGGCGCGCTCTTCACTGGAGGGCTTGCCGCCATCCTCGCCTCGGCTTGCTGCCTCGGGCCGTTGGTTCTGATCGCCTTGGGGTTCAGC 730 GCGCCGCGCGAGAAGTGACCTCCCGAACGGCGGTAGGAGCGGAGCCGAACGACGGAGCCCGGCAACCAAGACTAGCGGAACCCCAAGTCG

Fig. 5. Sequence of nucleotides 101-730 of Tn501 (Misra et al., 1984), showing the positions of those restriction sites used for the cloning and $\mathrm{S} 1$ mapping procedures described in the text. The EcoRI site in the inverted repeat of $\mathrm{Tn} 501$, used for some of the cloning experiments, is at position 13 (i.e. in front of the sequence shown here). The $\mathrm{N}$-terminal amino acid sequences for $\operatorname{mer} T$, and the entire amino acid sequence of merR (ORF3), as derived from the DNA sequence, are shown. The initiation and termination codons for ORFs 1 and 2 are boxed and labelled. Potential promoter regions $(-35$ and -10 sequences) are underlined, and the approximate points of initiation for the $m e r$ and $m e r R$ transcripts are indicated. The regions of dyad symmetry referred to in the Discussion are overlined, with a dot at the axis of symmetry.

as was seen in merR mutants of $\mathrm{R} 100$ (Ni'Bhriain et al., 1983). In the absence of $\mathrm{Hg}(\mathrm{II})$ and the presence of $m e r R$, the level of lac $Z$ expression is further reduced, and no transcript could be detected by $S 1$ mapping under these conditions, suggesting efficient repression of mer transcription by the mer $R$ product. A similar fragment from R100 (corresponding to positions 535-602 in $\mathrm{Tn} 501$ ) has previously been shown to confer $\mathrm{Hg}$ (II)-inducible tetracycline resistance in the presence of mer $R$ when placed upstream of a promoterless tetracycline resistance gene (Bohlander et al., 1981).

The different levels of $\beta$-galactosidase synthesized from the mer promoter cloned in the plasmids pRZ-ES-3 and pRZ-EB-3 in response to the same inducing levels of $\mathrm{Hg}$ (II) is probably due in part to the different abilities of these plasmids to mediate the transport of $\mathrm{Hg}$ (II) into the cell. pRZ-ES-3 contains the mer $T$ and $m e r P$ genes, which have been implicated in the uptake of $\mathrm{Hg}$ (II) (Foster et al., 1979; Ni'Bhriain et al., 1983; Ni'Bhriain, 1985). Strains containing this plasmid are hypersensitive to the presence of $\mathrm{Hg}(\mathrm{II})$ in the growth medium, presumably because they can transport $\mathrm{Hg}$ (II) into the cell but cannot detoxify it. Strains containing pRZ-EB-3, which require higher levels of $\mathrm{Hg}$ (II) to show maximal induction of $\beta$-galactosidase, do not show 
this hypersensitivity, and this plasmid contains DNA coding for only the first 27 amino acids of merT.

A plasmid which directed a low but measurable amount of $\beta$-galactosidase synthesis was produced by cloning the control region for ORF3 upstream of a promoterless lac $Z$ gene. This activity was considerably reduced when $m e r R$ or the chloramphenicol acetyltransferase-mer $R$ fusion polypeptide were present in the same cell. This reduction was unaffected by the presence of $\mathrm{Hg}(\mathrm{II})$. Nuclease $\mathrm{S} 1$ mapping showed the presence of a low level of transcription from this promoter, which presumably represents the repressed level of $m e r R$ transcription. We have not yet investigated the possibility of a transient derepression of $m e r R$ transcription on the uptake of $\mathrm{Hg}$ (II), such as has been reported for transcription of the AraC protein on the uptake of arabinose (Ogden et al., 1980, Hahn \& Schlief, 1983). Fragments of DNA upstream from ORFs 1 and 2 showed no detectable promoter activity. These data support the hypothesis that $m e r R$ is divergently transcribed with respect to the mer genes and represses its own synthesis.

The studies described here on Tn501 promoters were done using multi-copy vectors. It has been shown that estimates of promoter strength using such vectors are open to error in that significant copy number variation can occur as a result of the presence of different promoters in derivatives of the same vector (Adams \& Hatfield, 1984). Although this means that quantitative comparison of the promoters studied here with other cloned $E$. coli promoters is of dubious accuracy, it does not affect the main conclusions of this study. Induction studies are only over a short time-scale during which large fluctuations in copy number are unlikely to occur. Studies which showed repression of merR and mer transcription are internally controlled by comparisons between strains with either $\mathrm{pACYC184}$ or $\mathrm{pAC}-\mathrm{E}_{\mathrm{S}} \mathrm{E}_{\mathrm{L}}$ as the complementing plasmid. Also, studies on the R100 mer promoter produced the same results. The vector in this case is under stringent control for replication and hence not subject to copy number variation (Nisioka et al., 1969). The effects of copy number variation, as well as differential stability of mRNAs with different $3^{\prime}$ ends, may explain the different values for promoter strength of the derepressed mer promoters of R100 and Tn501 as assayed on pDU1161 and pRZ-H-2.

The DNA sequence in the regions involved in regulation reveals a number of features of interest which may be important in determining the interactions between regulatory proteins and DNA (Fig. 5). The control regions of Tn501 and R100 show almost complete sequence homology, which is as expected given the interchangeability of their mer $R$ gene products (Foster \& Ginnity, 1985; this work). In both Tn 501 and R100, the sequence TTGACT- $\mathrm{N}_{19}$-TAAGGT$\mathrm{N}_{7}$ is found upstream of the site of initiation of transcription of the mer genes as mapped in Tn501; this is close to the consensus $E$. coli promoter sequence of TTGACA-N ${ }_{17 / 19}$-TATAAT$\mathrm{N}_{5 / 7}$-start (Hawley \& McClure, 1983). Although positively regulated promoters often deviate quite markedly from this sequence (Raibaud \& Schwartz, 1984), the mer promoter is derepressed in the absence of the mer $R$ gene product and its similarity to the consensus promoter sequence is thus not surprising. There exists between the potential -35 and -10 sequences of the mer promoter a region of dyad symmetry (TCCGTAC-N 4 -GTACGGA, positions 559-576) which is perfectly conserved between $\mathrm{R} 100$ and $\mathrm{Tn} 501$, and is a possible binding site for a repressor protein. Another region of hyphenated dyad symmetry (TTGGCG-N ${ }_{4}$-CGCCAA) exists upstream from the -35 and -10 sequences at positions 505-520. In R100, the symmetrical sequence is reduced to TTGGC- $\mathrm{N}_{6}-\mathrm{GCCAA}$. Whether this sequence has any role in the control of transcription from the mer promoter is unknown although it could be a binding site for a positive regulatory protein. Further studies will be required to describe more fully the role of these different sequences in the regulation of mer transcription.

The control region for merR shows less homology between Tn 501 and R100, and is a less good match with the consensus promoter sequence. The region upstream of the mer $R$ transcription initiation site contains the sequence TTGTCC-N ${ }_{18}$-TAGCGT-N $\mathrm{N}_{9}$-start in Tn501 and TGGCCC- $\mathrm{N}_{18}$-TAGCGT- $\mathrm{N}_{9}$-start in R100 (assuming the start points of transcription are the same). The only obvious structure in the DNA around these regions that might be involved in regulation is the dyad symmetry between nucleotides 559 and 576, which overlaps the start point of $m e r R$ transcription and may hence be involved in the autoregulation of this gene, as well as repression of the mer promoter. 
Three regulatory proteins whose crystal structures have been wholly or partially solved (the products of the cro and $c$ I genes of bacteriophage $\lambda$, and the cAMP-binding protein) have been shown to possess a common structural motif which is thought to be involved in interacting specifically with their DNA binding sites (Anderson et al., 1981; Pabo \& Lewis, 1982; McKay \& Steitz, 1981). This consists of a pair of alpha helices linked by a tight bend. Other regulatory proteins whose amino acid sequence is known are also predicted to possess this structure (Pabo \& Sauer, 1984). Prediction of the secondary structure of the MerR protein using the method of McLachlan (1977) on the amino acid sequence predicted from ORF3 shows a high probability for a structure containing two alpha helices (residues 66-78 and 83-105 approx.) separated by a bend containing a glycine residue (Gly-79). A glycine residue is found at the bend between the known or predicted helices in 18 of the 21 regulatory proteins listed by Pabo \& Sauer (1984). Alignment of the predicted MerR amino acid sequence with that of the 21 other regulatory proteins presented by Pabo \& Sauer (1984), using this glycine residue as the reference point, shows a number of similarities between MerR and other regulatory proteins. Thus, if glycine is taken as position 0 , aliphatic amino acids are generally found at positions $-5,+6$ and +9 (leucine, alanine and leucine respectively in MerR). However, there is an arginine at position -4 (relative to the glycine at position 0 ) which is occupied by an aliphatic residue in most other regulatory proteins. One of the four cysteine residues which may be involved in binding the presumptive effector, $\mathrm{Hg}(\mathrm{II})$, occurs at the beginning of the second alpha helical region of the protein (Cys-82). The functional significance of these observations should become clearer following a more detailed biochemical and genetic analysis of the MerR protein and its interactions with DNA.

We thank Drs T. J. Foster, N. Ni'Bhriain, W. S. Reznikoff and S. Silver for communicating results prior to publication, W. S. Reznikoff for his kind gift of plasmid pRZ5255, and Drs M. J. Buttner, S. E. Halford, and N. Ni'Bhriain for useful discussion. L. Evans, D. Jacobs and S. E. Halford kindly provided enzymes, and M. J. Buttner helped with the SI mapping. This work was supported by the Medical Research Council and the Royal Society, of which N.L.B. is an EPA Cephalosporin Fund Senior Research Fellow.

\section{REFERENCES}

Adams, C. W. \& Hatfield, G. W. (1984). Effects of promoter strengths and growth conditions on copy number of transcription-fusion vectors. Journal of Biological Chemistry 12, 7399-7403.

Alton, N. K. \& VAPNEK, D. (1979). Nucleotide sequence analysis of the chloramphenicol resistance transposon Tn9. Nature, London 282, 868-869

Anderson, W. F., OHLendorf, D. M., TAKeda, Y. \& MatThEWS, B. W. (1981). Structure of the cro repressor from bacteriophage lambda and its interaction with DNA. Nature, London 290, 754-758.

Barrineau, P., Gilbert, P., Jackson, W. J., Jones, C. S., Summers, A. O. \& Wisdom, S. (1985). The DNA sequence of the mercury resistance operon of the IncFII plasmid NR1. Journal of Molecular and Applied Genetics 2, 601-619.

BERK, A. J. \& SHARP, P. A. (1977). Sizing and mapping of early adenovirus $m$ RNAs by gel electrophoresis of $\mathrm{S} 1$ endonuclease digested hybrids. Cell 12, 721-732.

De Boer, H. A., Comstock, L. J. \& Vasser, M. (1983). The tac promoter: a functional hybrid developed from the trp and lac promoters. Proceedings of the National Academy of Sciences of the United States of America 80, 21-25.

Bohlander, F. A., Summers, A. O. \& Meagher, R. B. (1981). Cloning a promoter that puts the expression of tetracycline resistance under the control of the regulatory elements of the mer operon. Gene 15, 395403.
Brown, N. L. (1985). Bacterial resistance to mercury: reductio ad absurdum? Trends in Biochemical Sciences $10,400-403$.

Brown, N. L., Ford, S. J., Pridmore, R. D. \& Fritzinger, D. C. (1983). Nucleotide sequence of a gene from the Pseudomonas transposon Tn50I encoding mercuric reductase. Biochemistry 22, 40894095.

BURGESs, R. R. (1969). A new method for the largescale purification of Escherichia coli deoxyribonucleic acid-dependent ribonucleic acid polymerase. Journal of Biological Chemistry 244, 6160-6167.

BuRgess, R. R. \& JENDRISAK, J. J. (1975). A procedure for the rapid, large scale purification of Escherichia coli DNA-dependent RNA polymerase involving polymin $P$ precipitation and DNA-cellulose chromatography. Journal of Biological Chemistry 14, 46364638.

Chang, A. C. Y. \& Cohen, S. N. (1978). Construction and characterisation of amplifiable multicopy DNA cloning vehicles derived from the P15A cryptic miniplasmid. Journal of Bacteriology 134, 11411156.

Clewell, D. B. \& Helinski, D. R. (1969). Supercoiled circular DNA-protein complex in Escherichia coli: purification and induced conversion to an open circular form. Proceedings of the National Academy of Sciences of the United States of America 62, 11591166. 
Dagert, M. \& Ehrlich, S. D. (1979). Prolonged incubation in calcium chloride improves the competence of Escherichia coli. Gene 6, 23-28.

FORD, S. J. (1981). Gene expression in the mercury resistance transposon $\mathrm{Tn} 501$. $\mathrm{PhD}$ thesis, University of Bristol, UK

Foster, T. J. \& BRown, N. L. (1985). Identification of the mer $R$ gene using mer-lac gene and operon fusions. Journal of Bacteriology 163, 1153-1157.

Foster, T. J. \& GinNity, F. (1985). Some mercurial resistance plasmids from different incompatibility groups specify mer $R$ regulatory functions that both repress and induce the mer operon of plasmid R 100 . Journal of Bacteriology 162, 773-776.

Foster, T. J., Nakahara, H., Weiss, A. A. \& Silver, S. (1979). Transposon A generated mutations in the mercuric resistance gene of plasmid R100.1. Journal of Bacteriology 140, 167-181.

HaHN, S. \& SCHLief, R. (1983). In vivo regulation of the Escherichia coli araC promoter. Journal of Bacteriology 155, 593-600.

Hawley, D. K. \& McClure, W. R. (1983). Compilation and analysis of Escherichia coli promoter sequences. Nucleic Acids Research 11, 2237-2255.

IsH-Horowicz, D. \& Burke, J. F. (1981). Rapid and efficient cosmid cloning. Nucleic Acids Research 9 , 2989-2998.

JaCkson, W. J. \& Summers, A. O. (1982). Polypeptides encoded by the mer operon. Journal of Bacteriology 149, 479-487.

Jones, B. B., Chan, H., Rothstein, S., Wells, R. D. \& REZNIKOFF, W.S. (1977). RNA polymerase binding sites in lambda-plac5 DNA. Proceedings of the National Academy of Sciences of the United States of America 74, 4914-4918.

Lambert, P. F. \& Reznikoff, W. S. (1985). Use of transcriptional repressors to stabilise plasmid copy number of transcriptional fusion vectors. Journal of Bacteriology 162, 441-444.

McFall, E. \& HeinCZ, M. C. (1983). Identification and control of synthesis of the $d s d C$ activator protein. Journal of Bacteriology 153, 872-877.

MCKay, D. B. \& Steitz, T. A. (1981). Structure of catabolite gene activator protein at $2.9 \AA$ resolution suggests binding to left-handed DNA. Nature, London 290, 744-749.

MCLaChlaN, A. D. (1977) Quantum chemistry and protein folding: the art of the possible. International Journal of Quantum Chemistry 12, supplement 1, 371385.

Maniatis, T., Fritsch, E. F. \& Sambrook, J. (1982). Molecular Cloning: A Laboratory Manual. Cold Spring Harbor, NY: Cold Spring Harbor Laboratory.

MaXAm, A. M. \& Gilbert, W. (1980). Sequencing endlabelled DNA with base-specific chemical cleavages. Methods in Enzymology 65, 449-560.

Melançon, P., Burgess, R. R. \& Record, M. T., JR (1982). Nitrocellulose filter binding studies of Escherichia coli RNA polymerase holoenzyme with deoxyribonucleic acid restriction fragments: evidence for multiple classes of nonpromoter interactions, some of which display promoter-like properties. Biochemistry 21, 4318-4331.
Messing, J. (1979). A multi-purpose cloning system based on the single-stranded bacteriophage M13. Recombinant DNA Technical Bulletin 2, 43-48.

MilleR, J. H. (1972). Experiments in Molecular Genetics. Cold Spring Harbor, NY: Cold Spring Harbor Laboratory.

MisRa, T. K., Brown, N. L., Fritzinger, D., Pridmore, R. D., Barnes, W. M., Haberstroh, L. \& SIL VER, S. (1984). Mercuric ion-resistance operons of plasmid R100 and transposon Tn501: the beginning of the operon including the regulatory region and the first two structural genes. Proceedings of the National Academy of Sciences of the United States of America 81, 5975-5979.

Misra, T. K., Brown, N. L., Haberstroh, L., Schmidt, A., Goddette, D. \& Silver, S. (1985). Sequence of mercuric reductase structural genes from plasmid R100 and transposon Tn501: functional domains of the enzyme. Gene 34, 253-262.

NI'BHRIAIN, N. N. (1985). Molecular genetic analysis of the merucric ion resistance (mer) operon of plasmid $R 100$. PhD thesis, Trinity College, University of Dublin, Ireland.

Ni'Bhriain, N. N., Silver, S. \& Foster, T. J. (1983). $\mathrm{Tn} 5$ insertion mutations in the mercuric ion resistance genes derived from plasmid R100. Journal of Bacteriology 155, 690-703.

Nisioka, T., Mitani, M. \& Clewes, R. C. (1969). Composite circular forms of $\mathrm{R}$ factor deoxyribonucleic acid molecules. Journal of Bacteriology 97 , 376-385.

Ogden, S., Haggerty, C. M., Stoner, D., Kolodnibetz, D. \& Schlief, R. (1980). The Escherichia coli L-arabinose operon: binding sites of the regulatory proteins and a mechanism of positive and negative regulation. Proceedings of the National Academy of Sciences of the United States of America 77, 3346-3350.

PABO, C. O. \& LewIS, M. (1982). The operator-binding domain of lambda repressor: structure and DNA recognition. Nature, London 298, 443-447.

PABo, C. O. \& SAUer, R. T. (1984). Protein-DNA recognition. Annual Review of Biochemistry 53, 293322.

Pestea, S., Daugherty, B. L., Jung, V., Hotta, K. \& PESTKA, R. K. (1984). Anti-mRNA: specific inhibition of translation of mRNA molecules. Proceedings of the National Academy of Sciences of the United States of America 81, 7525-7528.

Raibaud, O. \& Schwarz, M. (1984). Positive control of transcription in bacteria. Annual Review of Genetics 18, 173-206.

Robinson, J. B.-\& Tuovinen, O. H. (1984). Mechanisms of microbial resistance and detoxification of mercury and organomercury compounds: physiological, biochemical and genetic analyses. Microbiological Reviews 48, 95-124.

SANGER, F., Nicklen, S. \& Coulson, A. R. (1977). DNA sequencing with chain-terminating inhibitors. Proceedings of the National Academy of Sciences of the United States of America 74, 5463-5467.

Sil VER, S. \& MiSRA, T. K. (1984). Bacterial transformations of and resistance to heavy metals. In Genetic Control of Entironmental Pollutants, pp. 23-46. Edited by G. S. Omenn \& A. Hollander. New York \& London: Plenum Press. 
Silverstone, A. E., Arditti, R. R. \& Magasanik, B. (1970). Catabolite insensitive revertants of lac promoter mutants. Proceedings of the National Academy of Sciences of the United States of America 66, 773-779.

Stragier, P. \& Patte, J.-C. (1983). Regulation of diaminopimelate synthesis in Escherichia coli. III. Nucleotide sequence and regulation of the $l y s R$ gene. Journal of Molecular Biology 168, 333-350.

STUBER, D. \& BUJARD, H. (1981). Organisation of transcriptional signals in plasmids pBR322 and
pACYC184. Proceedings of the National Academy of Sciences of the United States of America 78, 167-171.

Summers, A. O. \& Silver, S. (1978). Microbial transformations of metals. Annual Review of Microbiology 32, 637-672.

WilcoX, G., Boulter, J. \& LeE, N. (1974). Direction of transcription of the regulatory gene $a r a C$ in Escherichia coli B/r. Proceedings of the National Academy of Sciences of the United States of America 71, 3635-3639. 